\title{
Violence in Crime-Appeal Programming and in Crime Statistics
}

\author{
A Content Analysis of Finnish Poliisi-TV
}

\author{
Mirka Smolej
}

\begin{abstract}
Numerous studies have noted that media representations of violent crime do not correspond to actual levels and features of violence in society. The present article examines whether this is true of the Finnish crime-appeal program Poliisi-TV. In addition, the article identifies similarities and differences in Finnish violence reporting in comparison with international research findings. The data consist of 23 episodes including 67 violence vignettes that are contrasted with statistical data on violence. Violence is highly over-reported in the program. A typical violent crime is an assault on the street at night between two previously unacquainted Finnish men, although reports on more hidden and rare types of violence are also prominent. Thus, the common generalization that crime media concentrate on the most violent and serious crimes perpetrated on the most vulnerable victims is disputed. The article discusses possible explanations for the differences among Anglo-Saxon and Nordic crime media contents and calls for more research on crime media's positive implications.
\end{abstract}

Keywords: crime media, media criminology, violence, crime-appeal programming, crime statistics, descriptive content analysis

\section{Introduction}

An overview of crime media studies (Reiner 2007: 378-393) points out several characteristics regularly found when using content analysis. First, crime stories are prominent in all media, and the amount has been constantly increasing since the Second World War (Davis and McLeod 2003). Second, the vast majority of stories are about serious violent crimes, whereas white-collar crime is underreported compared with victimization surveys and crime statistics (Surette 2002; Heber 2007). Third, offenders and victims in the media appear to be of higher status and older than those in crime statistics and the risk of victimization presented is more serious than it is in the real world. Fourthly, the effectiveness of the police and criminal justice system is portrayed in a favorable light, for example by overemphasizing the proportion of solved crimes. Finally, the media tend to focus on specific, individual cases and report little about wider trends, underlying causes or policy issues. (Reiner 2007: 378-393.)

Crime media is a popular research topic in several disciplines, particularly in sociology, communication studies, psychology, cultural studies and criminology. The present 
approach to studying media is criminological. The differences between the points of departures are not clear-cut, though some key elements define and separate criminological media research (e.g., media criminology) from other traditions.

Media criminology centers around three main areas of focus: the association between crime media and fear of crime, the connection between crime media and people's propensity to report about crimes to the police, and the relationship between media images of crime and public opinion (Kivivuori 2002a: 310-315). These three main interest areas can be and are often inter-connected. Thus, fear of crime can be seen to have an effect on the propensity to report crimes to the police or on individual attitudes. The main difference, in contrast to traditional communication studies, is that instead of being interested in the underlying structural causes of media violence criminology is focused on the possible implications and consequences of violent media content.

Thus, in traditional communication research, discussions about media as an industry, journalism as an institution, and analyses of the forces that might drive selection of media contents are not provided. The exclusion of such examinations does not undermine their importance or relevance. Instead, the aim is to present an alternative point of departure for researching media in the limited space of an individual article.

Particularly in criminology, the effects of crime media have mostly been seen as fundamentally subversive or as a form of social control. Basically, the former notion sees the media as a threat to law, order and morality, whereas the latter is worried about the exaggerated public alarm regarding crime cultivated by the media (Reiner 2007, 376-377). The predominance of these points of departure has led to a lack of empirical investigations on the possible positive implications of crime media. Thus, worries about the consequences of media representations of crime have generated a research industry that examines the content and implications of media crime stories (Reiner et al. 2003: 15), particularly in the UK and US, although similar research interests appear to be growing in the Nordic countries as well (Smolej and Kivivuori 2008).

In the present article, I examine how one crime-appeal program, Poliisi-TV (PTV), depicts violence. The focus is on the types of violence presented and on the representations of victims and offenders. The contents are contrasted with Finnish crime statistics for 2008 (CS) and with the most recent National Victimization Survey of 2006 (NVS). The objective is to examine the following research questions:

RQ1: Is violence in PTV distorted in a manner similar to what has been noted to be the case in various studies on crime media?

RQ2: What are the similarities and differences in Finnish violence reporting compared to previous research findings on crime media?

The vast amount of research shows that, regardless of the specific product or genre, representations of crime in the media are distorted (Reiner 2007), though the intensity of the distortion naturally depends on the definition of "crime media" in each individual study (Kitzinger 2004, 175). In the present article, "crime media" refers to crime news reporting and reality-crime programming and does not include examinations or references to fictional media. 


\section{Crime - Appeal Programming}

Nabi et al. (2003: 304) have defined reality television programs as filming real people as they are living out events in their lives, contrived or otherwise, as these events occur. However, during recent years, the concept and definition of reality television has broadened and fragmented, because there is huge variation in programs and formats that fall into the category (Baruh 2009).Moreover, increasing numbers of crime programs are constantly being introduced to the viewers.

Particularly troublesome for the study of reality TV sub-genres is that scholars appear to group programs based on personal impressions of similarity rather than on either clearly defined program characteristics or on viewers' perceptions of common themes (Nabi 2007: 372). In the present article, I follow Kafatou-Haeusemann's (2007: 85) definitions of reality-crime programming. She notes that this TV genre consists of two separate formats: reality-based police shows and crime-appeal programs. The former format presents and justifies the police as the authoritarian agents of crime control, whereas the latter provides heroic space for ordinary citizens. Common features of all reality-crime programs seem to be the tendency to overemphasize street crime, visually dramatic elements, fast pace and strong emotional appeal (Hallin 2000: 269).

The two format types also differ from each other regarding program contents. In reality-based police shows, the audience is seemingly in the backseat of a police car and present during police encounters. The focus of crime-appeal programs is instead more on crime victims as well as on their families and friends, who are often interviewed about a crime. Showing video footage and photos of actual or suspected perpetrators in order to interest the public in calling in to the program and helping the police catch the criminal is a distinctive characteristic of crime-appeal programs.

Reality-crime broadcasting justifies its existence by claiming to provide a twofold public service function: first, to help the police capture wanted offenders and to clear up unsolved criminal cases and, second, to warn the public about certain kinds of criminal victimization (Kafatou-Haeusermann 2007: 90). Much of the enduring success of realitycrime programs lies in the way they respond to and perpetuate our culture's perennial fascination with identifying and seeing both criminals and victims (Jermyn 2003: 175).

Crime-appeal programming has not been previously studied in Finland. In the Nordic and continental Europe context, as well, there is very little academic research on the crime-appeal program genre (however see Dalhquist 2000; Kafatou-Haeusermann 2006; Brants 1998; Dauncey 1998). The domination of British and American studies may well distort the overall picture of crime media contents on a global scale. Thus, it is essential to study crime media outside the Anglo-Saxon context.

\section{Data and Methods}

The target of the present study, PTV, is a weekly Finnish crime-appeal program. It has aired since 1989 and has several sister programs around the world. Of the programs familiar to the author, PTV most closely resembles Efterlyst (Sweden) and Crimewatch (UK). Like other crime-appeal programs, PTV also claims to present true stories about crime, criminals and victims. In this respect, it is a hybrid form of programming: it resembles aspects of the news and entertainment programs (Cavender and Fishman 1998). One major difference in comparison to most crime-appeal programs is that PTV airs 
via one of the state-owned television channels, YLE TV2, and is thus not commercially financed.

Altogether, 23 episodes, including 148 crime vignettes, aired autumn $2005(\mathrm{n}=59)$, spring $2006(n=31)$ and spring $2008(n=58)$ have been digitally saved. Year 2007 was not included in the data due to a lack of research funding. Because of technical problems related to the Finnish digitalization process, all intended episodes from 2006 were not successfully saved. Therefore, the final number of saved vignettes varies across the years studied.

This raw data consists of 12 hours of material. In the first phase of the data analysis, content analysis was utilized in filtering and organizing the topics of the vignettes into headlines in a SPSS matrix. Each vignette serves as a unit of analysis. Related to this phase, all vignettes were watched through several times and some preliminary notes were made about the overall contents and construction of the material. In the present article, the term vignette refers to a news-clip or an interview related to a recent criminal incident.

In the second phase, all vignettes handling violence have been transcribed to text. The main analytic phase was to include all stories that reported some kind of real violence. Only intentional non-fictional criminal violence and attempts at intentional violence were included. Stories about harassment and bullying at school or work have also been included. Traffic accidents caused by drunk driving have been excluded. Related to this process, quantitative elements of the contents were collected and coded to the matrix. The coding protocol included quantifiable indicators of victim and perpetrator demographics, type of offense, and of the relationship between perpetrator and victim.

It is evident that strict quantitative analysis may result in the exclusion of valuable content that cannot be reduced to numeric form. Therefore, it has also been necessary to examine the qualitative traits found in the vignettes. This enables an examination of the more subtle elements of crime media, such as dramatization and emotivistic techniques. The analytical framework can be described as twofold: first, as obtaining an overview through basic quantitative analysis and, second, as taking the analysis in a qualitative direction by using strict definitions of the targeted data contents (see also Lindgren 2008: 97-98). Thus, descriptive content analysis has been utilized (Reiner et al. 2003), meaning that quantitative data have been supplemented with verbal and visual elements in order to illustrate central quantitative elements in the data. The following data excerpt shows what the final transcribed vignette looks like. In this example, a woman is talking about how being assaulted had affected her:

Living was [a color photo of the injured face, the camera zooms closer] difficult with the hand, and my face was totally in pieces and my glasses broken... So I don't have that many memories, because I don't think I was able to do much then. Probably I was just trying to get better [laughs a little].

The final PTV data consist of 67 violence vignettes from the years 2005, 2006 and 2008, which are contrasted with CS 2008 and NVS 2006 data. The CS data are available for the public on the Internet via Statistics Finland's homepage. The NVS data have been accessed for the purpose of this study with the permission of the National Research Institute of Legal Policy, which hosts the data collection and analysis together with Statistics Finland. Some of the examined variables are available only through one of the 
statistical sources, but information from both sources is provided whenever possible. However, because the PTV data were gathered during three years, all presented figures should be treated as descriptive instead of representative.

It is important to underline that the police records and victimization surveys produce different, even conflicting, pictures of crime and violence, and that there are several pitfalls in interpreting the meaning of these statistics (Maguire 2007; Sparks 1992). For example, the official statistics on crime do not include incidents that have not been reported to the police. Thus, changes in recorded crime statistics do not always reflect changes in criminal activity (see Kivivuori 2002b: 2-3). The victimization surveys also have their limits, including the problem of "hidden crime", and include several unique problems of measurement (see Coleman and Moynihan 1996).

\section{Amount and Type of Violence}

Forty-three per cent of the program content deals with violence ${ }^{1}$. The portrayed crime types are presented more closely in Table 1.

Table 1. Violence in PTV by Presented Offenses

\begin{tabular}{lrc} 
Crime types & $\%$ & N \\
\hline Assault & 30 & 20 \\
Homicide & 25 & 17 \\
Robbery & 10 & 7 \\
Rape & 10 & 7 \\
Organized crime & 7 & 5 \\
Ethnic violence & 4 & 3 \\
Bullying/harassment & 4 & 3 \\
Human trafficking/kidnapping & 4 & 3 \\
Rioting & 3 & 2 \\
\hline Total & 100 & 67
\end{tabular}

The most common violent act portrayed in the program is assault, constituting one third of the total contents. Assaults usually take place on the street, at night and between strangers. Homicides are the second most common violence vignettes. The variation between circumstances and perpetrator and victim traits is extensive.

Every tenth violence vignette in PTV portrays robberies. They are commonly victimless in the sense that no human victim of the crime is named or shown. The robberies have typically occurred in stores or kiosks, and the vignette is accompanied by video surveillance footage of the suspect. Rapes are as common in the program as robberies are. The victims are rarely interviewed, and when they are, their faces and voices are blurred to prevent identification. Stories on organized crime deal with motorcycle club violence and drug offenses. Ethnic violence includes stories of so-called honor violence, where Muslim women are interviewed about their experiences of violence. There are three vignettes both on bullying and harassment in school and at work, and three stories on human trafficking. Two vignettes concern a large riot that took place in Helsinki in 2006. 
The amount of violence in PTV is highly exaggerated when compared to reported crime. According to CS 2008, over half of the committed offenses in Finland are traffic offenses. Property crimes constitute one third of the total amount. Crimes of violence (including sex crimes) constitute fewer than 5 per cent of all recorded crime. The NVS 2006 data indicate that approximately ten per cent of Finns end up as victims of violence or threats (Sirén et al. 2007: 2). Thus, other than violent crime, especially traffic offenses and white-collar crime are heavily under-represented in PTV. The PTV findings are consistent with previous research on media contents (Surette 2002; Reiner 2007), although the distortion between the media and statistics is not as drastic in PTV (43\%) as appears to be the case in other reality-crime programs. For example, studies on reality-crime programming in the US and UK have reported the proportions of violent crime to be 87 per cent (Oliver 1994), 84 per cent (Kooistra 1998) and 72 per cent (Cotter et al. 2008).

\section{Offender and Victim Characteristics}

Reality-crime portrayals of crime, criminals and victims are distorted in a manner very similarly to portrayals in crime news: crimes are violent, criminals are men and victims are women (e.g., Oliver 1994; Cavender and Bond-Maupin 1993; Dahlquist 2000). In addition, research has directed particular attention to four elements of victim and perpetrator traits: age, ethnicity, gender, and the relationship between the parties involved. In what follows, I will also examine how the place of violence is presented in PTV.

\section{Age}

Criminal offending is one of a number of psychosocial disorders that are characteristic of youth in the sense that they increase in prevalence in adolescence or early adulthood (Smith 2002: 702). Violence is no exception to this rule (Aaltonen et al. 2008). For example, according to CS 2008, the vast majority of robberies are committed by young men, and young people - young men in particular - are also the most likely victims of violence (Lehti et al. 2009: 70-71). The NVS 2006 data indicate that younger people are generally far more often victimized by violence than are older people. The same applies to both men and women, although women's overall victimization levels are lower (Lehti et al. 2009: 78).

The most common age group committing crimes of violence in PTV is 21 to 30 years of age (Table 2), constituting nearly one third of all cases. It is almost as common that all information about the perpetrator is absent from the vignette. Sometimes this is because there have been no eyewitnesses to the crime, sometimes because emphasis is put on other issues, for example on portrayals of the missing goods. In one-fifth of the vignettes, more than one person is suspected of having committed the crime. Both particularly young and old perpetrators are rare in the footage. Thus, in portraying people under 30 as the most crime active group, PTV conveys a picture that is rather consistent with the statistics.

The victims in PTV are somewhat older than the perpetrators, most commonly in the age group 31 to 60 years. Nearly one-fourth of the vignettes portray more than one victim for an individual crime. Vignettes lacking a crime victim are rarer than cases without a personalized perpetrator. A typical case lacking a victim is a grocery store robbery, 
Table 2. Age of Violence Suspect and Victim in PTV (\%)

\begin{tabular}{lcc} 
& Suspect & Victim \\
\hline Under 20 & 7 & 16 \\
$21-30$ & 27 & 6 \\
$31-60$ & 16 & 34 \\
Over 60 & 1 & 5 \\
More than one suspect/victim & 22 & 24 \\
Missing & 25 & 15 \\
\hline Total & 100 & 100
\end{tabular}

where video footage and computer constructions of the suspect are shown, but details of the incident are not told and the victim(s) is not identified. The victims in PTV are somewhat older than the perpetrators, although the proportion of individuals under 20 years of age is over twice as large among victims as among perpetrators. Moreover, old people are slightly more often portrayed as victims than as perpetrators. Still, both very young and very old victims are not the most typical victims in the program.

These findings on PTV portrayals are not consistent with previous research. According to Jewkes (2004: 37), in crime media, the victim's age is often stated if and when it fits to the range of criteria of the programs newsworthiness. Therefore especially vulnerable victims, such as children and old people, are considered good and worthy, ideal victims (Christie 1986), and they appear frequently in news reports. For example, in Crimewatch, girls, young women, and elderly people are typical victims (Jewkes 2004: 155), and according to Leishman and Mason (2003: 13), a typical street mugging victim in the (British) media is a vulnerable old lady whose handbag has been snatched.

\section{Gender}

Certain trends and patterns in criminality regarding gender have long been observed. These include that women commit a small proportion of all crimes, and that crimes committed by women are fewer, less serious, more rarely professional, and less likely to be repeated (Heidensohn 2002: 491). For example, in 2008, only 10 per cent of robbery suspects in Finland were women (Lehti et al. 2009: 70). Regarding all crime types, the percentage was 19 (Honkatukia 2009: 233). Previous research on crime media has also found that the majority of violence portrays men as perpetrators (Kafatou-Haeusermann 2007: 342; Cavender et al. 1999) and women as victims (Kafatou-Haeusermann 2007: 351).

PTV portrayals of suspects are dominated by men (Table 3). Men are suspects in over half of all the violence vignettes, whereas the percentage of women is only seven. There are several suspects in nearly one third of the vignettes. In these cases, gender is usually not stated, and it is also impossible to determine otherwise. These include crimes such as gang fights, school bullying and rioting. In nine per cent there is either no knowledge of the perpetrator's identity or no reference to a perpetrator. The data include, for instance, a vignette of a bank van robbery in which nothing is said about the perpetrator or victim/s. 
Table 3. Violence Perpetrator's Gender (\%)

\begin{tabular}{lrcc} 
& PTV & CS 2008 & IVS 2006 \\
\hline Male & 55 & 70 & 83 \\
Female & 7 & 11 & 12 \\
Several/both & 28 & - & - \\
Unknown/missing & 9 & 19 & 5 \\
\hline Total & 100 & 100 & 100
\end{tabular}

The proportion of men among violence suspects in PTV corresponds rather well to both the information on CS and the IVS data, although the large percentage of multiple suspects in PTV makes the direct comparison challenging.

According to police statistics, men end up as victims of violence more often than women do (e.g., Lehti et al. 2009: 71), but the types of violence experienced differ significantly among men and women. Particularly domestic violence towards women is often left undetected by the police (Aromaa and Heiskanen 2000: 128-131). Men experience more stranger-violence, whereas among women the perpetrator is often previously known (Honkatukia 2009: 243). These tendencies are partly reflected on the IVS findings (Table 4), which indicate no quantitative difference in violence experiences among men and women.

The most common violence victims in PTV are men (Table 4), although the proportion of exclusively female victims is thrice as large among victims as it is among perpetrators. In one fifth of the cases, there are multiple victims for one crime, and in ten per cent the victim's gender is not known or not stated. Men's higher prevalence as victims is consistent with the CS data, and does not conflict with IVS findings either, although the rather large proportion of several victims in PTV should be taken into account.

Table 4. Violence Victim's Gender (\%)

\begin{tabular}{lccc} 
& PTV & CS 2008 & IVS 2006 \\
\hline Male & 43 & 62 & 50 \\
Female & 25 & 35 & 50 \\
Several/both & 21 & - & - \\
Unknown/missing & 10 & 3 & - \\
\hline Total & 100 & 100 & 100
\end{tabular}

The examination does not support previous findings on crime media's tendency to over-emphasize female crime victims (Kafatou-Haeusermann 2007: 351; Jewkes 2003), but on the contrary indicates that female violence victims are under-represented in PTV.

\section{Ethnicity}

Finland is an ethnically homogenous country. In 2006, the percentage of foreign nationality citizens was $2.3^{2}$. During recent years, most foreigners living in Finland have originated from Estonia, Russia and Sweden (Niemi et al. 2009: 251). These are also the 
largest minority groups based on spoken languages in Finland (Suomen väestö 2009). According to statistics, in 2008, six per cent of all persons suspected of offenses known to police in Finland were foreigners. A majority of them were Russians, Estonians and Swedes, and they were most often suspected of traffic offenses. Regarding violent crime, foreigner suspects were over-represented in rapes and robberies (Niemi et al. 2009: 252-4). Studies of foreigners and immigrants as crime victims in Finland indicate that they commonly suffer from many varieties of discrimination, including attacks of racist violence (Niemi et al. 2009).

Studies on crime media, mostly conducted in the US and UK, have stated that crime-reality programs tend to over-represent crimes involving black offenders and under-represent black victims, especially males in both categories (Oliver and Armstrong 1995; Jewkes 2003: 161). Also gang, gun and knife violence is often attached to particular ethnic groups (Sveinsson 2008). The same tendency has been seen the German reality-crime program XY, which portrays 62 per cent of all perpetrators as foreigners (Kafatou-Haeusermann 2007: 345). A study examining the contents of Cops (Cotter et al. 2008: 283), on the other hand, indicated that the majority of both suspects and victims in the program are white. Still, non-whites are most likely to be responsible for violent crime, whereas whites are suspected more often of property crimes and domestic violence.

The findings on PTV are not consistent with the above findings. Only eight per cent of the perpetrators in PTV are non-Finnish, whereas according to CS 2008 the percentage is 29. The proportion of foreign violence suspects in PTV is not only remarkably smaller than previous studies suggest, but also differs significantly from the picture transmitted by crime statistics. The same trend applies to foreign violence victims. According to CS, the proportion in 2008 is 13 per cent, whereas in PTV the percentage is six. No single ethnic group is highlighted in the footage. Thus, the examination indicates that ethnic minorities are heavily under-represented in PTV, both as violence suspects and as violence victims. This finding might be partly explained by the fact that the largest ethnic minorities in Finland are Russians and Estonians, who do not differ in physical appearance from the general population.

\section{Relationship}

PTV strongly over-emphasizes "stranger-danger" in its footage (Table 5). In most cases, the perpetrator is a complete stranger to the victim and/or to the police. The proportion is drastically distorted when compared with data from CS and IVS. Violence among family members and friends is also heavily under-reported in the program.

Table 5. Victim's Prior Relationship to Perpetrator

\begin{tabular}{lccc} 
& PTV & CS 2008 & IVS 2006 \\
\hline Unknown & 72 & 29 & 48 \\
Spouse, relative & 13 & 15 & 11 \\
Friend, acquaintance & 15 & 34 & 33 \\
Missing & - & 22 & 8 \\
\hline Total & 100 & 100 & 100
\end{tabular}


On the other hand, PTV vignettes portraying violence among family members and relatives corresponds well with both statistical sources. These topics feature vignettes, for example, on domestic violence and honor violence. This suggests that PTV has a more nuanced concept of violence than do its Anglo-American sister-programs, which contain only few reports on every-day violence (Reiner 2007). Moreover, although the proportion of strangers as violence perpetrators is exaggerated, in PTV they are not so much presented as "faceless predators" (Surette 2002: 69), but instead merely as unidentified, anonymous characters.

\section{Place of Violence}

According to both PTV and IVS, the most common place for violence is the street (Table 6), and the proportions of violence in private homes and the victim's workplace are also rather consistent between the two data sources. The major differences are connected with the proportions of bar violence and with the category of missing information.

Table 6. Place of Violence (\%)

\begin{tabular}{lcc} 
& PTV & IVS 2006 \\
\hline Street & 34 & 24 \\
Private home & 19 & 24 \\
Victim's workplace & 18 & 23 \\
Bar, restaurant & 3 & 20 \\
Missing & 25 & 9 \\
\hline Total & 100 & 100
\end{tabular}

Bars and restaurants appear as settings for violence nearly seven times less often in PTV as they do in IVS. This might be explained by the fact that the majority of cases are reported to the police and solved with help from witnesses. Thus, the need for the assistance of crime media is less in these cases. Another inconsistency between the two sources is the proportion of missing information. In PTV, one fourth of the vignettes do not specify the place of violence. Examples of these include vignettes in which the crime has supposedly occurred abroad and cases in which the place the victim was found is suspected to be different than the actual crime scene.

Overall, PTV exaggerates street-violence in its footage, but the proportion is not as drastically distorted as it appears to be in international comparisons (Surette 2002; Hallin 2000). In addition, PTV's tendency to report on more mundane forms of violence is reflected in the proportions of private homes and workplaces as settings for violence.

\section{Findings}

The amount of violence in PTV is highly over-represented in comparison to both CS 2008 and NVS 2006 data. Crimes such as assaults, homicides and robberies are staples of PTV, accounting for nearly half of all crime-related content shown in the program. A typical violent crime in PTV is an assault that happens on the street between strangers at night. Usually both the suspect and the victim are adult Finnish men. Violence also overrides other topics, especially traffic offenses and white-collar crime. 
Although the general trend to overemphasize violent crime found in numerous previous studies on reality-crime programs (Kooistra et al. 1998: 147; Carmody 1998; Cavender and Bond-Maupin 1993; Oliver 1994) is true for PTV, the overall amount is not as drastically distorted as it is in other reality-crime programs. In PTV, violence constitutes "merely" 43 per cent of the overall contents, whereas findings from American and British studies indicate double proportions (Cotter et al. 2008).

The proportion of different types of violence in the program is consistent with previous studies showing homicide and street-violence to be the main topics in crime media (Oliver 1994; Surette 2002). On the other hand, representations of sex crime are not as common in PTV as appears to be the case elsewhere (see for example Greer 2003: 64; Jewkes 2003: 155). Thus, although highlighting untypical crimes, PTV also includes reports on more hidden and rare types of violence, including harassment and ethnic violence.

PTV reflects well the statistical picture of violence perpetrators, portraying 21- to 30 -year-olds as the most common suspect group. The portrayals of violence victims (adult men) are also consistent with statistics. However, in contrast to previous research, PTV's portrayals of victims do not adhere to the principle of "worthy" or "ideal" victims (Christie 1986). On the contrary, the proportions of both particularly young and old victims are under-represented in the program. The division of gender in PTV is also consistent with statistics: men are portrayed both as violence perpetrators and as violence victims. Unlike in previous research (Kooistra et al. 1998: 149-150; Dalhqvist 2000), women are under-reported as violence victims in PTV.

Ethnic minorities are heavily under-reported both as violence suspects and as victims in PTV. This finding differs significantly from the results of previous research. In fact, the finding that ethnic minorities (especially blacks) are over-represented in reality crime programs is probably the second common finding in media criminology, right after the notion that violence is highly exaggerated.

The proportion of strangers as violence perpetrators is exaggerated in PTV, as is the amount of street violence. These findings are consistent with other studies on crime media (Cavender et al. 1999; Kafatou-Haeusermann 2007: 355; Hallin 2000). On the other hand, the amount of violence between family members and relatives corresponds to the CS and IVS data rather well. In contrast to previous findings (Reiner 2007), in PTV violence also takes place in private homes and in work environments. These findings are interesting, because they confirm the over-emphasis on "stranger-danger", but also indicate that more hidden types of violence can be and are reported in reality-crime programs.

\section{Conclusion}

Violence in PTV is not portrayed in such black-and-white terms as it is in American and British crime media. For example, the common generalization that reality-crime programs concentrate on the most violent and serious crimes, such as murder and rape, perpetrated on the most vulnerable victims, young women, girls and elderly women (Jewkes 2003: 155), is disputed. Neither are violence victims in PTV the "virginal married mothers of small children" as in the US (Cavender et al. 1999), but more likely adult males, just as in the statistics. Moreover, the vulnerable old lady who is appar- 
ently a major figure in the Anglo-Saxon media (Leishman and Mason 2003: 13) is not found in PTV.

It has been proposed (Smolej 2010) that one major reason for differences in crime media contents among Anglo-Saxon countries and Finland lies in the varying cultural contexts. Particularly vulnerable victims, such as old people or children, are still considered too vulnerable to be utilized in media reports in Finland. Second, crime and criminal policy is not at all a central political theme, which probably has more to do with the construction of the political system than with actual crime levels ${ }^{3}$. The emphasis on crime and control in the political agenda appears to be considerable stronger in countries with two-party systems (for example the US and UK) than in countries with multi-party systems, such as Finland. These differences are also reflected in the mass media, as extreme political polarization of the press is still rare in Nordic countries. Third, it is likely that because PTV airs on a state-owned TV channel, both the selection of news contents and the ways in which the vignettes are constructed and presented in the program differ significantly from corresponding commercial programs.

PTV makes numerous exceptions to the reality-crime program genre by transmitting a more nuanced picture of violence. Some violence topics, including ethnic violence and harassment, seem to be a speciality of PTV. Moreover, some victim and perpetrator traits, such as age, ethnicity and gender, are not as strongly highlighted or distorted in PTV as they appear to be in its American and British sister-programs. It is also likely that similar findings could be obtained in other Nordic countries, where crime reporting does not take as sensationalistic forms as it does in the UK and US.

Research has shown that there is no single viewing audience but many different audiences that bring their personal experiences to their interpretations of media content (Doyle 2003: 53). Moreover, besides studying media effects on individual audience members, it is perhaps even more important to understand how the media influence other institutions (ibid.; Estrada 1999; Pollack 2001).

The long-lasting concerns over harmful media effects that have led to the predominance of problem-based research (Nabi and Oliver 2009: 2) - particularly in crime media research - are in dire need of re-orientation in the future. It has already been noted in video game studies that such games can be used as a form of relaxation and therapy (Gardner 1991) and act as a means to release pent-up aggression and frustration. There are no reasons to assume that crime media do not offer excitement, a feeling of danger or enable cathartic experiences (Presdee 2000), or have numerous other positive implications both for viewers and readers, and for society as a whole. Such programs can draw attention to certain issues, for instance highlight victims' rights and even influence government policies. Crime media also play a major role in uncovering and publicizing miscarriages of justice and have positive effects on victims. (Marsh and Melville 2009: 110-2.)

\section{Notes}

1. The non-violent crime contents (53\%) consist of property crimes, hunting crimes, traffic offenses, arsons and frauds. Missing persons is a permanent topic, as are reports on the functions of the crime controlling system. In addition, a vignette featuring a patrolling police team accompanied by a reporter on their weekend shift is included in every episode. 
2. The same percentage, for example, in Sweden was 5.4, in Denmark 5.1 and in the United Kingdom 5.8 (Tilastokeskus, 2009).

3. Finland is a violent country in comparison to other Western states. For example, the homicide rate is one of the highest in the EU (Lehti, 2008).

\section{References}

Aaltonen, M., V. Hinkkanen, J. Kivivuori and R. Sirén (2008) Risk Factors of Violence in Finland: A RegisterBased Study. Research Brief 6: 2008. Helsinki: National Research Institute of Legal Policy [Online]. Retrieved October 8, 2009 from: http://www.optula.om.fi/uploads/qibmvhg1hzf.pdf

Aromaa, K. and M. Heiskanen (2000) Väkivalta ja uhkailu. In Heiskanen, M., K. Aromaa, H. Niemi and R. Sirén Tapaturmat, väkivalta, rikollisuuden pelko. Väestöhaastatteluiden tuloksia vuosilta 1980-1997 [Accidents, Violence, Fear of Crime. Survey Findings from 1980-1997]. Helsinki: Oikeuspoliittisen tutkimuslaitoksen julkaisuja 171. Tilastokeskus, Oikeus 2000:1.

Baruh, L. (2009) Publicized Intimacies on Reality Television: An Analysis of Voyeuristic Content and Its Contribution to the Appeal of Reality Programming. Journal of Broadcasting \& Electronic Media 53(2): 190-210.

Brants, C. (1998) Crime Fighting by Television in the Netherlands. In Fishman, M. and G.. Cavender (eds.) Entertaining Crime. Television Reality Programs. New York: Aldine De Gruyter.

Carmody, D.C. (1998) Mixed Messages. Images on Domestic Violence on "Reality" Television. In Fishman, M. and G. Cavender (eds.) Entertaining Crime. Television Reality Programs. New York: Aldine De Gruyter.

Cavender, G. and M. Fishman (1998) Television Reality Programs: Context and History. In Fishman, M. and G. Cavender. (eds.) Entertaining Crime. Television Reality Programs. New York: Aldine De Gruyter.

Cavender, G., and L. Bond-Maupin (1993) Fear and Loathing on Reality-Television: An Analysis of "America's Most Wanted" and "Unsolved Mysteries". Sociological Inquiry (63): 305-317.

Cavender, G..L. Bond-Maupin and N.C. Jurik (1999) The Construction of Gender in Reality Crime TV. Gender \& Society 13(5): 643-663.

Christie, N. (1986) The Ideal Victim. In Fattah, E.A (ed.) From Crime Policy to Victim Policy. Reorienting the Justice System. Basingstoke: MacMillan.

Coleman, C. and J. Moynihan (1996) Understanding Crime Data. Buckingham and Philadelphia: Open University Press.

Cotter, R., W. de Lint and D. O'Connor (2008) Ordering Images: Cooking Reality in COPS. Journal of Criminal Justice and Popular Culture 15(3): 277-290.

Dahlquist, U. (2000) Veckans Brott. En studie av våld i reality-tv program. [A study of violence in reality television]. Stockholm: Medierådets publikation 24 [Online]. Retrieved October 8, 2009 from: http:// www.medieradet.se/upload/Rapporter_pdf/Nr_24_Veckans_brott.pdf

Dauncey, H. (1998) "Temoin No. 1": Crime Shows on French Television. In Fishman, M. and G. Cavender (eds.) Entertaining Crime. Television Reality Programs. New York: Aldine De Gruyter.

Davis H. and L. McLeod (2003) Why Humans Value Sensational News. An Evolutionary Perspective. Evolution and Human Behavior 24: 208-216.

Doyle, A. (2003) Arresting Images: Crime and Policing in Front of the Television Camera. Toronto: University of Toronto Press.

Estrada, F. (1999) Ungdomsbrottslighet som samhällsproblem. Utveckling, uppmärksamhet och reaktion. [Juvenile Delinquency as a Social Problem] Kriminologiska Institutionen. Stockholm.

Gardner, J.E. (1991) Can the Mario Brothers Help? Nintendo Games as an Adjunct in Psychotherapy in Children. Psychotherapy 28: 667-670.

Greer, C. (2003) Sex Crime and the Media. Sex Offending and the Press in a Divided Society. Devon: Willan Publishing.

Hallin, D.C. (2000) La Nota Roja: Popular Journalism and the Transition to Democracy in Mexico. In Sparks, C. and J. Tulloch (eds.) Tabloid Tales. Global Debates over Media Standards. Lanham. Maryland: Rowman \& Littlefield.

Heber, A. (2007) Var rädd om dig! Rädsla för brott enligt forskning, intervjupersoner och dagspress. [Fear of crime according to research, interviews and daily press] Stockholm: Kriminologiska Institutionen.

Heidensohn, F. (2002) Gender and Crime. In Maguire, M., R. Morgan and R. Reiner (eds.) Oxford Handbook of Criminology ( $3^{\text {rd }}$ Edition). New York: Oxford University Press.

Honkatukia, P. (2009) Naiset rikosten tekijöinä ja uhreina [Women as perpetrators and victims of crime]. In Rikollisuustilannekatsaus 2008. Rikollisuus- ja seuraamusjärjestelmä tilastojen valossa. Helsinki: Oikeuspoliittisen tutkimuslaitoksen julkaisuja 247.

Jermyn, D. (2003) Photo stories and family albums: imaging criminals and victims on Crimewatch UK. In Mason, P. (ed.) Criminal Visions: Media Representations of Crime and Justice. Devon: Willan Publishing. 
Jewkes, Y. (2004) Media \& Crime. Key Approaches to Criminology. Sage: London

Kafatou-Haeusermann, M. (2007) The Media-Crime Nexus Revisited: On the Re-Construction of Crime and Law-and-Order in Crime-Appeal Programming. Berlin: Max-Planck-Institut für ausländisches und internationales Strafrecht.

Kivivuori, J. (2002a) Kriminologin näkökulma rikosuutisointiin. [A criminologist's perspective on crime news] Oikeus 31(3): 310-317.

Kivivuori, J. (2002b) Piilorikollisuuden tutkimus [Methods of measuring crime]. In Kivivuori, J. (ed.) Nuoret rikosten tekijöinä ja uhreina [Trends and patterns of self-reported juvenile delinquency in Finland]. Oikeuspoliittisen tutkimuslaitoksen tutkimuksia 188: Helsinki.

Kitzinger, J. (2004) The Debate about Media Influence. In Greer, C. (ed.) (2009) Crime and Media. A Reader. Routledge: London and New York.

Kooistra, P.G., J.S. Mahoney and S.D. Westervelt (1998) The World of Crime According to "Cops". In Fishman, M. and G. Cavender (eds.) Entertaining Crime. Television Reality Programs. New York: Aldine De Gruyter.

Lehti, M. (2008) Henkirikoskatsaus 2008 [Homicides]. Oikeuspoliittisen tutkimuslaitoksen verkkokatsauksia 8/2008 [Online]. Retrieved October 8, 2009 from: http://www.optula.om.fi/44658.htm

Lehti, M., R. Sirén, Hinkkanen, V. and Aaltonen, M. (2009) Muut väkivaltarikokset. [Other crimes of violence]. In Rikollisuustilannekatsaus 2008. Rikollisuus ja seuraamusjärjestelmä tilastojen valossa [Crime Trends in Finland 2008]. Helsinki: Oikeuspoliittisen tutkimuslaitoksen tutkimuksia 247.

Leishman, F. and P. Mason (2003) Policing and the Media: Facts, Fictions and Factions. Cullompton: Willan Publishing.

Lindgren, S. (2008) Crime, Media, Coding: Developing a Methodological Framework for Computer-Aided Analysis. Crime, Media, Culture 4(1): 95-100.

Maguire, M. (2007) Crime Data and Statistics. In Maguire, M., R. Morgan and R. Reiner (eds.) Oxford Handbook of Criminology ( $3^{\text {rd }}$ ed). New York: Oxford University Press.

Marsh, I. and G. Melville (2009) Crime, Justice and the Media. Oxon and New York: Routledge.

Nabi, R.L. and M. Oliver (2009) (eds.) SAGE Handbook of Media Processes and Effects. Thousand Oaks: Sage.

Nabi, R.L., E.N. Biely, S.J. Morgan and C. Stitt (2003) Reality-based Television Programming and the Psychology of its Appeal. Media Psychology 5(4): 303-330

Nabi, R. (2007) Determining Dimensions of Reality: A Concept Mapping of the Reality TV Landscape. Journal of Broadcasting and Electronic Media 51(2), 371-390.

Niemi, H., P. Honkatukia and M. Lehti (2009) Ulkomaalaiset, maahanmuuttajat ja rikollisuus [Foreigners, immigrants and criminality]. Rikollisuustilannekatsaus 2008. Rikollisuus- ja seuraamusjärjestelmä tilastojen valossa. Helsinki: Oikeuspoliittisen tutkimuslaitoksen julkaisuja 247.

Oliver, M. and B. Armstrong (1995) Predictors of Viewing and Enjoyment of Reality-based and Fictional Crime Shows. Journalism Quarterly 72(3): 559-570.

Oliver, M. (1994) Portrayals of Crime, Race, and Aggression in "Reality-Based" Police Shows: a Content Analysis. Journal of Broadcasting \& Electronic Media 38:2, 179-192.

Pollack., E. (2001) En studie i medier och brott. [A study on media and crime] Stockholm: Stockholms Universitet, Institutionen för journalistik, medier och kommunikation.

Presdee, M. (2000) Cultural Criminology and the Carnival of Crime. London: Routledge.

Reiner, R. (2007) Media Made Criminality. The Representation of Crime in the Mass Media. In Maguire, M., R. Morgan and R. Reiner (eds.) Oxford Handbook of Criminology ( $3^{\text {rd }}$ ed.). New York: Oxford University Press

Reiner, R., S. Livingstone and J. Allen (2003) From Law and Order to Lynch Mobs: Crime News Since the Second World War. In Mason, P. (ed.) Criminal Visions. Media Representations of Crime and Justice. Devon: Willan Publishing.

Sirén, R., J. Kivivuori, J. Kääriäinen and M. Aaltonen (2007) Suomalaisten kokema väkivalta 1980-2007 [Violence in Finland 1980-2007]. Helsinki: Oikeuspoliittisen tutkimuslaitoksen tutkimustiedonantoja 74.

Smith, David J. (2002) Crime and the Life Course. In Maguire, M., R. Morgan and R. Reiner (eds.) Oxford Handbook of Criminology ( $3^{\text {rd }}$ ed.). New York: Oxford University Press.

Smolej, M. and J. Kivivuori (2008) Crime News Trends in Finland: A Review of Recent Research. Journal of Scandinavian Studies in Criminology and Crime Prevention 9(2): 202-219.

Smolej, M. (2010) Constructing Ideal Victims? Violence Narratives in Finnish Crime-Appeal Programming. Crime, Media, Culture 6(1): 69-85.

Sparks, R. (1992) Television and the Drama of Crime. Buckingham: Open University Press.

Suomen väestö 2008. [Population of Finland] (2009) Helsinki: Tilastokeskus.

Surette R. (2002) Media, Crime and Criminal Justice. Images and Realities. $2^{\text {nd }}$ edition. Belmont, CA: West/ Wadsworth. 
Sveinsson, K.P. (2008) A Tale of Two Englands - "Race" and Violent Crime in the Press. Runnymede Trust Publications [Online]. Retrieved October 8, 2009 from: http://www.runnymedetrust.org/publications/95/184.html

Tilastokeskus (2009) Maailma numeroina. Väestö ja väestönmuutokset. [Statistics Finland: World in Numbers], [Online]. Retrieved October 8, 2009 from: http://www.tilastokeskus.fi/tup/maanum/taulukot.html

MIRKA SMOLEJ, Planner, Department of Criminal Policy, Ministry of Justice Government, Finland, mirka.smolej@helsinki.fi 